REVIEW

\title{
Intestinal adaptation after massive intestinal resection
}

\author{
A R Weale, A G Edwards, M Bailey, P A Lear
}

Postgrad Med J 2005;81:178-184. doi: 10.1136/pgmj.2004.023846

Patients with short bowel syndrome require long term parenteral nutrition support. However, after massive intestinal resection the intestine undergoes adaptation and nutritional autonomy may be obtained. Given that the complications of parenteral nutrition may be life threatening or result in treatment failure and the need for intestinal transplantation, a more attractive option is to wean patients off nutrition support by optimising the adaptive process. The article examines the evidence that after extensive small bowel resection adaptation occurs in humans and focuses on the factors that influence adaptation and the strategies that have been used to optimise this process. The review is based on an English language Medline search with secondary references obtained from key articles. There is evidence that adaptation occurs in humans. Adaptation is a complex process that results in response to nutrient and non-nutrient stimuli. Successful and reproducible strategies to improve adaptation remain elusive despite an abundance of experimental data. Nevertheless given the low patient survival and quality of life associated with other treatments for irreversible intestinal failure it is imperative that clinical research continues into the optimisation of the adaptation.

See end of article for authors' affiliations

Correspondence to: Mr A R Weale, Department of Surgery, Southmead Hospital, North Bristol NHS Hospitals Trust, Westbury on Trym, Bristol BS10 5NB, UK; andy@weale.org.uk

Submitted 7 May 2004 Accepted 29 July 2004
$\mathrm{S}$ hort bowel syndrome occurs when the functioning gut mass is reduced below the amount necessary for adequate digestion and absorption of food and fluid. ${ }^{1}$ Although the absorptive function of the intestine does not always correlate with residual bowel length, short bowel syndrome is usually defined anatomically as less than $30 \%$ of normal intestinal length $(<75 \mathrm{~cm}$ in children and $<200 \mathrm{~cm}$ in adults). In the failing intestine the inability to absorb nutrients, fluids, and electrolytes eventually leads to clinical deficiencies, and if an increase in oral intake is not sufficient to compensate for this malabsorption, parenteral nutritional support is required. European practices vary, but overall the incidence and prevalence of home parenteral nutrition (HPN) is six patients per million per year and four patients per million population respectively. ${ }^{2}$ Intestinal failure is the indication for $\mathrm{HPN}$ in $59 \%$, with the rest requiring nutritional support because of cancer or AIDS. Parenteral nutrition is associated with significant morbidity, mortality, and a reduced quality of life. ${ }^{34}$ As such alternative treatments for intestinal failure have been considered.
$\mathrm{PN}$ related liver failure, repeated catheter sepsis, or venous thrombosis with loss of vascular access, result in failure of parenteral therapy. ${ }^{5}$ In patients who can no longer receive parenteral support small bowel transplantation has been performed. The results of transplantation for intestinal failure using either an isolated intestine or composite grafts (liver and intestine or multivisceral including intestine), have improved but remain disappointing. One year graft/patient survival for transplants performed after 1999 in large centres (>10 transplants), are $60 \% / 80 \%, 60 / 65 \%, 65 \% / 70 \%$ for isolated intestinal, liver-intestinal, and multivisceral transplants respectively. ${ }^{6}$ Overall five year graft and patient survival from the USA are $20 \%$ and $51 \%$ respectively. $^{7}$

A more attractive option is to wean patients off parenteral support. After extensive gut resections it has been observed that the need for permanent support is difficult to predict. $^{8}$ Such patients requiring home parenteral therapy continue to take fluids and nutrition orally. Over time, the intestine seems to adapt to the extent that some patients with short bowel lengths can autonomously maintain acceptable fluid, electrolyte, and nutritional balances.

The aim of this article is to evaluate the direct and indirect evidence that adaptation occurs in humans after extensive small bowel resection, review the factors that influence adaptation, and assess the strategies that have been used in attempts to optimise this process.

\section{EXPERIMENTAL EVIDENCE FOR ADAPTATION (SEE BOX)}

In rodent systems, animals subjected to extensive $(>70 \%)$ intestinal resection undergo a pattern of well described morphological and functional changes. The remaining intestine changes macroscopically with dilatation, thickening, and an increase in length. ${ }^{9}$ There is an increase in villus height and diameter, and an elongation of the crypts. An increase in epithelial cellular proliferation, coupled with a decrease in apoptosis, produces increases in intestinal RNA, DNA, and protein content. ${ }^{10-13}$ The changes are increased with more extensive resections and the most pronounced changes occur in the ileum. ${ }^{14}$

Functionally there is an increase in absorption per unit length of carbohydrates, proteins, water,

Abbreviations: HPN, home parenteral nutrition; SCFA, short chain fatty acid; LCFA, long chain fatty acid; IGF-I, insulin-like growth factor I; IGF-II, insulin-like growth factor II; EGF, epidermal growth factor; TGF $\alpha$, transforming growth factor $\alpha$; HBEGF, heparin binding epidermal epidermal-like growth factor; GLP2, glucagonlike peptide 2; HGF, hepatocyte growth factor 
and electrolytes. ${ }^{12}$ Indeed within six hours there is upregulation of the sodium-glucose cotransporter, the dominant mechanism by which fluid and electrolytes are handled by the small intestinal enterocyte. ${ }^{15}$

\section{Changes associated with experimental} adaptation

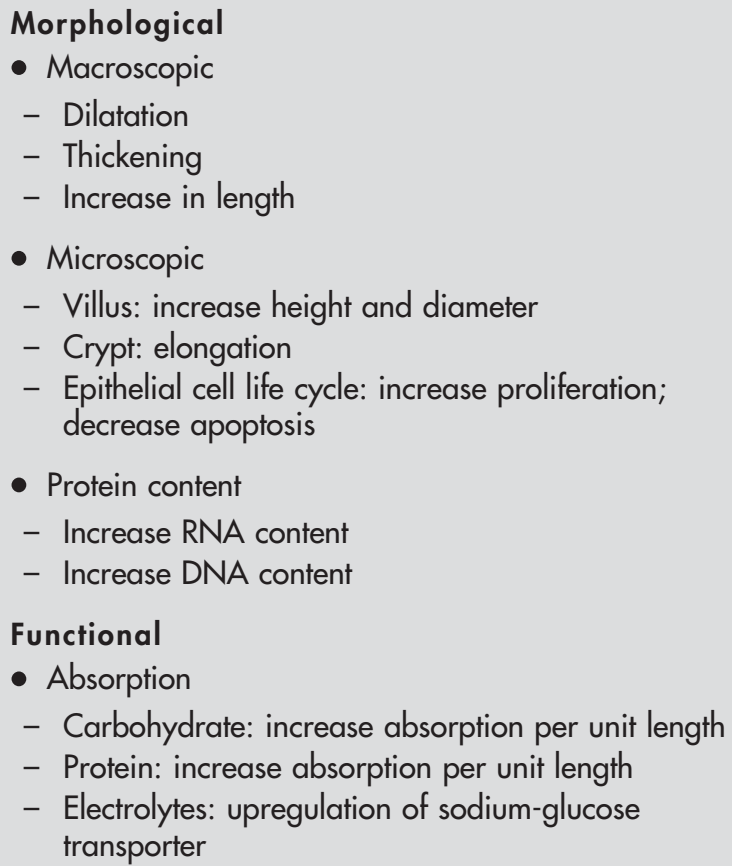

\section{HUMAN EVIDENCE FOR ADAPTATION}

The direct evidence for such changes in humans is limited. Although the macroscopic changes of intestinal hypertrophy and lengthening have been described, the changes in villus/ crypt architecture described in rodents have not been reproduced by most studies. ${ }^{12} 1316$

Functional changes have been shown to occur in humans, both in the small and large intestine. Xylose and calcium absorption increases per unit length after resection and continues to increase for at least two years. ${ }^{17}$ The oligopeptide transporter, PepTl, the $\mathrm{H}^{+}$dependent mechanism for transport of di-peptides and tri-peptides in the gastrointestinal tract, has been shown to be up-regulated in colon but not the small intestine. ${ }^{16}$

Indirect evidence that adaptation of the intestine occurs comes from the fact that patients with very short bowel lengths can become independent of the need for parenteral nutrition after a period of months or even years. Whether a patient can be weaned from parenteral nutrition is dependent on a number of factors. The length of small bowel ${ }^{8}$ and the presence of colon ${ }^{18}{ }^{19}$ are particularly important. Other factors that are useful in predicting whether intestinal failure is permanent are the time on parenteral nutrition ( $>2$ years) and the amount of energy the patient can derive from enteral feeding. ${ }^{8}{ }^{20-22}$

Other indirect evidence comes from patients who receive live related segmental intestinal transplants, in whom only $180-200 \mathrm{~cm}$ of ileum is transplanted. ${ }^{23}{ }^{24}$ These grafts do undergo morphological and functional adaptation, with an increase in villus area of up to $50 \%{ }^{25}$ and normal carbohydrate and fat absorption tests by six months. ${ }^{26}$
NORMAL INTESTINAL EPITHELIAL HOMOEOSTASIS

The intestinal epithelium is a continually renewing single cell layer sheet, containing four different columnar cell types, which is folded into invaginated crypts and finger-like villi. The cell lineages include the absorptive enterocyte (columnar lineage), which is the majority cell $(>96 \%)^{27}$ and three types of secretory cell (mucus lineage): the goblet cell; the enteroendocrine cell, and the crypt Paneth cell. All types of epithelial cell within the intestine are derived from multipotent stem cells found near the base of the crypts. ${ }^{28}$

Mouse studies have shown that in steady state conditions the absorptive enterocyte, the goblet cell, and the enteroendocrine cell all migrate and differentiate over a period of two to five days from the crypt upwards to the villus tip, whereupon they are lost. ${ }^{29}$ The Paneth cells complete their differentiation and remain within the crypt for around 20 days, at which point they are removed by phagocytosis. ${ }^{30}$ Each crypt contains 250-300 epithelial cells, and it is estimated in the intestine of an adult mouse that there are about $10^{6}$ crypts. $^{29}$ In these animals, stem cells produce equivalent to $1 \mathrm{~g}$ ( $10^{9}$ cells) of new epithelial cells every five days. ${ }^{31} 32$

An increase in proliferation of crypt cells, coupled with a decrease in apoptosis, increases the villus height and a total increase in DNA, RNA, and protein content. Proliferation therefore requires a supply of polyamines, putrescine, spermidine, and spermine, which are organic cations, influencing DNA, RNA, and tissue synthesis. ${ }^{33}$ Nutrient and non-nutrient factors are purported to have a role in intestinal epithelial cell turnover in both steady state conditions and after extensive resection.

\section{NUTRIENT FACTORS INVOLVED IN ADAPTATION \\ Amino acids}

Enteral feeding is the primary source of amino acids for intestinal tissue as, apart from glutamine, there is little or no arterial uptake of any amino acids. ${ }^{34}$ Glutamine, rather than glucose, is the major fuel for mitochondrial respiration in enterocytes. ${ }^{35}$ Glutamine is used for protein synthesis either directly or as a result of catabolic pathways.

Within 24 hours of $80 \%$ small bowel resection in the rodent, glutamine and total amino acid uptake per gram of tissue is increased. ${ }^{36}$ However, with the decrease mass of tissue, overall glutamine consumption in the long term is less than controls ${ }^{37}$ and muscle stores of glutamine remain unchanged. ${ }^{38}$ The addition of glutamine or arginine to enteral feeds after extensive resection does not seem to produce a consistent effect between studies, indeed there is little evidence that either amino acid increases adaptation and some groups have reported lower protein and DNA levels than controls. ${ }^{39-44}$ Supplementation of enteral feeds with ornithine $\alpha$ ketoglutarate (OKG), the soluble ornithine salt, does seem to have a positive effect on intestinal morphology and mucosal polyamine synthesis. ${ }^{45}$

\section{Carbohydrates}

Luminal enzymes, such as amylase, digest polysaccharide carbohydrate into oligosaccharides and disaccharides. Oligosaccharides and disaccharides are hydrolysed to monosaccharides by intestinal membrane brush border enzymes, such as disaccharidases. Disaccharidase activity increases significantly after resection. ${ }^{42} 45$

The monosaccharides are absorbed by the enterocyte by facilitative and active dependent transport. Glucose absorption is by sodium dependent transporters both actively, via SLGT 1, and down concentration gradients, via GLUT 2 and GLUT $5 .{ }^{46}$ The expression of SGLT 1 is transiently increased after experimental resection. ${ }^{15} 46$ 
Short chain fatty acids (SCFA), such as butyrate, are produced by bacterial hydrolysation and fermentation of carbohydrates and proteins that reach the colon undigested. SCFA can be absorbed by colonocytes and provide energy. Complex carbohydrates such as fibre are one such source of SCFA in the diet. Diets high in fibre and butyrate have been shown to increase the content of DNA, RNA, and protein per unit weight of small intestine mucosa after resection in rodents compared with controls. ${ }^{47}$

In humans, fermentation of non-digested carbohydrate in the colon to SCFA can result in a decrease in luminal $\mathrm{pH}$ and an overgrowth in D-lactate producing bacteria, such as Lactobacillus acidophilus, Lactobacillus fermenti, and streptococcus. This may result in D-lactic acidosis, ${ }^{58}$ which presents with non-hepatic encephalopathy, ataxia, dysarthria, and severe metabolic acidosis. Management requires low carbohydrate diets and supportive treatments, such as dialysis. ${ }^{48}$

\section{Lipids}

The main mechanism of lipid absorption is by passive diffusion, although the evidence for protein facilitated transfer is accumulating. ${ }^{49-51}$ Fatty acid binding protein $(\mathrm{I}-\mathrm{FABP})^{52}$ and fatty acid translocase $(\mathrm{FAT} / \mathrm{CD} 36)^{53}{ }^{54}$ are expressed in the intestine and upregulated after resection in rodents. ${ }^{556}$ However, this is not accompanied by the increased intestinal uptake of long chain fatty acids (LCFA). ${ }^{57}$

Essential fatty acids may be required for optimal adaptation after resection. Rats fed fatty acid deficient diets had reduced mucosal hyperplasia compared with controls. ${ }^{58}$ However, a low fat normo-caloric diet, reduces but does not abolish the adaptive response. ${ }^{5659}$

LCFAs, such as arachiodonic acid and eicosapentaenoic acid also contribute towards the adaptive response. ${ }^{60}$ Supplementation of the diet with linoleic acid or medhaden oil both produce increases in adaptive changes compared with controls. ${ }^{6162}$ LCFA, may exert their effects by arachiodonic acid metabolites such as prostaglandin. ${ }^{60}$ Inhibition of prostaglandin by administration of aspirin, or cyclo-oxygenase inhibitors only reduces the expected adaptive response of the distal ileum. ${ }^{60}{ }^{63}$ Unfortunately, patients with extensive distal small bowel resections have reduced bile salt concentrations in the duodenum as re-absorption normally occurs in the ileum. This leads to a decrease in micellar solubilisation, and malabsorption of LCFA in particular.

\section{EFFECTS OF PARENTERAL NUTRITION (SEE BOX)}

In normal rodents maintained on parenteral nutrition with no luminal nutrition there is significant mucosal hypoplasia, with lower mucosal protein and DNA content, and increases in apoptosis accompanied by decreases in mitoses in the villus and crypt. ${ }^{64}{ }^{65}$ After extensive experimental gut resections, the adaptive response is limited but not abolished when no nutrition is provided orally. ${ }^{66-70}$ Scarce data exist regarding the effects on healthy human subjects. In eight volunteers, nutrition was provided parenterally for 14 days. The investigators found subtle mucosal changes, with an increase in intestinal permeability and a decrease in jejunal biopsy mucosal thickness attributable solely to a decrease in villus cell count. ${ }^{71}$ A small randomised human study showed that short term addition of glutamine to TPN prevented the increase in permeability and loss of villus height. ${ }^{72}$

\section{DIET TYPES}

Elemental diets are liquid feeds containing protein as free amino-acids, carbohydrates as glucose or simple sugars, fat as small quantities of defined essential fatty acids, plus vitamins and minerals. ${ }^{73}$ The elemental diet is theoretically more easily absorbed. In patients with short bowel syndrome, studies have found $n^{74}$ or little ${ }^{75}$ difference in protein, energy, or fluid absorption between complex or elemental diets. Indeed providing nutrition to rodents only as an elemental diet produces mucosal hypoplasia. ${ }^{76} 77$

\section{NON-NUTRIENT FACTORS INVOLVED IN ADAPTATION}

Table 1 gives a summary of the factors involved in adaptation.

\section{Growth hormone and insulin-like growth factors}

In rodent systems growth hormone has been shown to promote adaptation by increasing bowel length and function per unit length. ${ }^{78}{ }^{79}$ Human trials have been performed and these are discussed later.

Growth hormone mediates its trophic effects by insulinlike growth factor-I (IGF-I). ${ }^{33} 8081$ IGF-I produces its main biological actions through the type 1 insulin-like growth factor receptor ${ }^{81}$ which is distributed uniformly on epithelial cells through the small intestine, but is present to a higher degree in the colon..$^{82}$ In serum, IGF-I is bound to circulating binding proteins (insulin like growth factor binding proteins (IGFBP)). The IGFBPs can also have independent effects on cell growth; for example IGFBP-3, the predominant binding protein, has pro-apoptotic activity. ${ }^{83}$

Growth hormone stimulates IGF-I production in the liver and locally within the intestine, leading to an increase in serum and intestinal IGF-I. ${ }^{80}{ }^{84}$ Normal small bowel epithelium expresses little of no IGF-I. ${ }^{81}$ Treatment of human duodenal biopsy specimens with IGF-I significantly increased crypt cell proliferation rate, ${ }^{80}$ while administration of IGF-I and glutamine to rodents increases total ileal DNA content after resection, suggesting that IGF-I induces proliferation in vivo. ${ }^{85}$ Exogenous IGF-I given to rodents strongly increases IGFBP-5 mRNA in the jejunal lamina propria and muscularis, while growth hormone produces modest increases in IGFBP-5 mRNA in the muscularis only. ${ }^{81}{ }^{86}$ IGFBP-5 stimulates proliferation in isolated human intestinal smooth muscle cells, both independent of IGF-I, and by potentiating the effect of IGF-I-receptor interaction. ${ }^{87}$

The role of IGF-I in human short bowel syndrome in vivo is yet to be evaluated. Several studies have reported a link between raised serum IGF-I, in the presence of low levels IGFBP-3, with increased risks of breast, ${ }^{88}$ prostate, ${ }^{89}$ colorectal, ${ }^{90}$ and lung ${ }^{91}$ cancers. As such human trials of IGF-I may prove ethically difficult to perform.

Insulin-like growth factor II (IGF-II), which is important for normal development and growth, has also been studied. However there is little evidence that parenteral administration of IGF-II produces significant changes in villus height, crypt depth, or small bowel weight after experimental resection. ${ }^{92}$ Indeed rats given IGF-II after resection lose weight compared with baseline and controls. ${ }^{92}$

\section{Epidermal growth factors}

The family of epidermal growth factors, includes epidermal growth factor (EGF), transforming growth factor $\alpha$ (TGF $\alpha)$, and heparin binding epidermal-like growth factor (HBEGF). ${ }^{93}$ All bind the epidermal growth factor receptor (c-erb B-1 $)^{93}$ that is expressed on the basolateral surface of intestinal epithelial cells. ${ }^{94}$ EGF is produced by the Brunner glands of the duodenum and in salivary glands. ${ }^{95}$ Increases in EGF improve the normal adaptive response after extensive rodent small bowel resection. ${ }^{96}{ }^{97}$ Reduction of circulating EGF or inhibition of EGF receptor reduces adaptation in rodent models. ${ }^{98} 99$

$\mathrm{TGF} \alpha$ is produced by the gastrointestinal epithelium, mainly by fully mature villus enterocytes ${ }^{100}{ }^{101}$ and stimulates epithelial cell proliferation in vitro. Exogenous TGF $\alpha$ increases the adaptive response after experimental resection, 


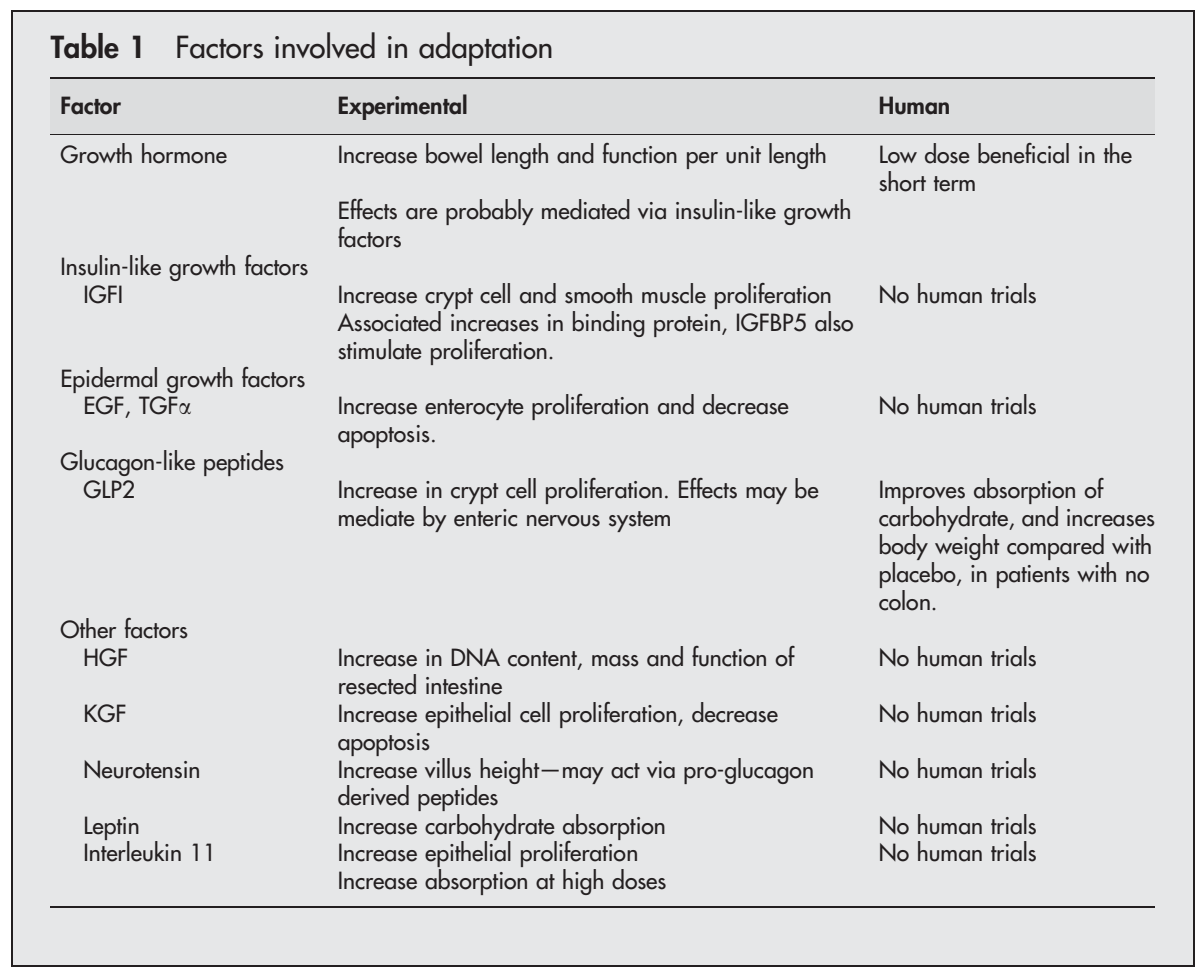

with increased epithelial cell proliferation and decreased apoptosis. $^{102}$

HBEGF, a powerful mitogen for epithelial cells, is expressed in a number of tissues, including the intestinal epithelium itself. ${ }^{103} 104$ In vitro the expression of HBEGF mRNA is upregulated in injured culture intestinal epithelial cells. ${ }^{105}$ In vitro stimulation of pre-adipocyte cells via the IGF receptor produces selective upregulation of HBEGF mRNA. ${ }^{106}$ HBEGF may therefore play a part in the mitogenic effect of IGF-I.

\section{Glucagon-like peptides}

Proglucagon derived peptides are secreted from the intestinal mucosa after ingestion of food and may be important in adaptation. ${ }^{107}$ Nude mice with subcutaneous proglucagon producing tumours show signs of intestinal epithelium proliferation. Glucagon-like peptide 2 (GLP2) was proposed to be the derivative of proglucagon responsible, as parenteral administration of GLP2 produced an increased bowel length, and villus height in both jejunum and ileum. ${ }^{108}$ GLP2 stimulates intestinal epithelial proliferation in vitro. ${ }^{109}$ After resection of $>75 \%$ of the intestine in rodents, parenteral GLP2 increased the intestinal diameter, crypt-villus ratio, sucrase activity, total protein, and DNA per centimetre of jejunum but not the ileum when compared with controls. ${ }^{110}$

The role of endogenously produced GLP2 has been studied in experimental resection models. It is secreted by L-type entero-endocrine cells on nutrient stimulation. These cells are situated mainly in the distal small intestine and colon. ${ }^{94}$ In rodents, resection followed by oral feeding produces increased expression of proglucagon mRNA in the ileum, with an associated sustained increase in plasma GLP2, and a large increase in observed crypt cell mitoses. Resection, followed by parenteral nutrition alone, produced a transient increase in plasma GLP2 and an increased expression of proglucagon mRNA of the colon. Resection produced a significant adaptive response in both groups; however in the resection/parenteral nutrition group there was only a modest increase in crypt mitoses. ${ }^{70}$
In mice, the mRNA encoding the receptor for GLP2 (GLP2R) is expressed in the intestine. However, it seems that GLP2R is expressed only on enteric neurons ${ }^{27}$ and not entero-endocrine cells as previously reported. ${ }^{111}$ These neurons lie in the submucosal plexus and most of their projections are in the sub-epithelial region around the crypts. Blocking enteric neurons using tetrodotoxin suppresses the proliferation of epithelial cells in response to GLP2. ${ }^{27}$ The evidence for the influence of GLP2 on the enteric nervous system is added by the finding it may also increase gut transit time. ${ }^{112}$

\section{Other factors}

A number of other factors have been shown to increase adaptation but not studied extensively.

Hepatocyte growth factor (HGF) and its receptor c-Met are expressed in many tissues including the intestine. ${ }^{100}$ After massive experimental resection, intestinal mass and function are increased with administration of HGF compared with controls. ${ }^{113}$ There is evidence that HGF produces increases in the gene expression of glucose transporters, SGLTl and GLUT5. ${ }^{114}$

Keratinocyte growth factor induces epithelial cell proliferation and up-regulates antiapoptotic factors in the intestine. ${ }^{115}$ It is produced locally in the gut by intraepithelial lymphocytes and stromal cells in the lamina propria. ${ }^{116}$ Parenteral administration of KGF has been shown to increase adaptation in a $\mathrm{rat}^{117}$ and a mouse ${ }^{118}$ model of short bowel syndrome.

Neurotensin, a 13-amino acid peptide is produced mainly by $\mathrm{N}$-type entero-endocrine cells in the ileum, ${ }^{77}$ and released normally after fat ingestion. When given exogenously, neurotensin has been shown to increase the villus height but increases in intestinal mass compared with control animals after massive intestinal resection have not been reproduced between studies. ${ }^{119}{ }^{120}$ The effects of neurotensin may be mediated by pro-glucagon derived peptides. ${ }^{120}$

Leptin is produced by adipocytes, and regulates thermogenesis and appetite. ${ }^{121}$ The initial study that located leptin receptors in the small intestine, concluded that, in normal 
rats, administration of leptin inhibits sugar absorption. ${ }^{122}$ However, other studies have shown that leptin seems to increase carbohydrate absorption in the intestine of normal ${ }^{123}$ and massively restected rats. ${ }^{121}$ DNA content and mucosal mass were not increased by leptin in the short bowel syndrome model.

Interleukin 11 (ILl1) is a bone marrow derived cytokine that has been shown to have effects on numerous tissues including the blood, central nervous system, reproductive organs, and the gut. ${ }^{124}$ It has been shown experimentally to reduce gastrointestinal mucosal injury caused by chemotherapy and radiation ${ }^{125}{ }^{126}$ by increasing mitoses in crypt cells. In a resection model of short bowel syndrome in rats, ILl 1 administration increases mucosal thickness, with proliferation of enterocytes, ${ }^{127}$ but only at high doses can it increase carbohydrate absorption. ${ }^{128}$

\section{OPTIMISING ADAPTATION IN CLINICAL PRACTICE}

Attempts to maximise the number of patients who can be weaned off PN have been made by optimising the adaptive process using strategies based on experimental short bowel systems described previously.

\section{Growth hormone and glutamine}

Uncontrolled cohort studies have shown that $40 \%$ of patients with short bowel syndrome, were independent of HPN within one year of treatment with 28 days high dose growth hormone $(0.09 \mathrm{mg} / \mathrm{kg} /$ day $)$, continual glutamine $(30 \mathrm{~g} /$ day $)$ and high fibre diet supplementation. ${ }^{129} 130$ A more recent report has found that this strategy was more successful in patients with a preserved colon. ${ }^{131}$

Three small, randomised controlled trials using growth hormone have been performed. Scolapio and colleagues ${ }^{132}$ randomised eight patients with short bowel syndrome, dependent on HPN (>3 years), to receive a 21 day course of either active treatment or placebo. Active treatment involved growth hormone $(0.14 \mathrm{mg} / \mathrm{kg} /$ day $)$, glutamine and a high carbohydrate, low fat diet ( $1500 \mathrm{kcal} /$ day $)$. Patients crossed over to the other treatment arm at three weeks. There were no significant differences in basal metabolic rate, carbohydrate absorption, villus/crypt morphology, or crypt cell proliferation. There was however a significant increase in sodium and potassium absorption, and a delay in gastric emptying in the treatment group. All patients gained weight because of oedema, but any positive effects were not sustained. ${ }^{133}$

A second trial ${ }^{134}$ examined the effect of four weeks high dose growth hormone $(0.12 \mathrm{mg} / \mathrm{kg} /$ day $)$ and glutamine, with no change in diet, in eight patients, all of whom had been dependent on HPN for at least one year. No significant changes in absorption of energy, wet weight, carbohydrate, sodium, potassium, calcium, magnesium, or nitrogen were found five days after withdrawal of treatment. All patients complained of side effects during the treatment arm of the study, including peripheral oedema, carpal tunnel syndrome, and gynaecomastia.

The most recent randomised cross over trial ${ }^{135}$ has found a positive effect with three weeks treatment of low dose growth hormone $(0.05 \mathrm{mg} / \mathrm{kg} /$ day $)$ in combination with an unrestricted hyperphagic diet ( $>$ onefold estimated basal metabolic rate, with at least $1 \mathrm{~g}$ protein $/ \mathrm{kg} /$ day). Twelve adult patients with short bowel syndrome, dependent on HPN for at least one year, were included, and patients assessed for five days after treatment. Significant increases in lean body mass and absorption of energy, nitrogen, carbohydrate, and fat were found after treatment compared with controls. The mean (SD) increase in intestinal absorption corresponded to 37\% (16\%) of total HPN energy delivery. Although this study only examined the short term results, the potential longer term effects of this treatment may have an impact on parenteral nutrition dependence.

\section{Glucagon-like peptide}

The normal rises in plasma concentrations of GLP2 after a test meal, are reduced in size and duration in HPN patients who have undergone massive small bowel resection and colectomy. ${ }^{112}$ However, patients with intestinal failure who had a preserved colon have increased fasting GLP2 and an increased meal stimulated response compared with age match controls. ${ }^{136}$ Administration of GLP2 may improve nutrient absorption in patients with no colon. Eight patients, with short bowel syndrome, all of whom had undergone ileal and colonic resection were given $400 \mu \mathrm{g}$ of GLP2 subcutaneously twice daily for five weeks. Improvements with treatment compared with controls were seen in intestinal absorption of energy, wet weight, and nitrogen, as well as increases in lean body mass and overall body weight. There were no changes in transit time. There were minimal adverse effects described and patient compliance was good. ${ }^{137}$ However, only four patients in this study actually required home PN.

\section{CONCLUSION}

Adaptation is a complex process that results in response to nutrient and non-nutrient stimuli. Successful and reproducible strategies to increase adaptation remain elusive despite an abundance of experimental data. Given the small number of patients with irreversible intestinal failure, conducting trials with sufficient power in appropriate populations is difficult. Unless multicentre studies are undertaken the evidence for the effectiveness of treatments designed to increase adaptation is likely to remain weak. Nevertheless given the low patient survival and quality of life associated with other treatments for irreversible intestinal failure it is imperative that research continues into the optimisation of the adaptation.

\section{Authors' affiliations}

A R Weale, A G Edwards, P A Lear, Department of Surgery, Southmead Hospital, North Bristol NHS Hospitals Trust, Westbury on Trym, Bristol, UK

A R Weale, A G Edwards, M Bailey, Molecular and Cellular Biology, Division of Veterinary Pathology Infection and Immunity, University of Bristol, Langford, UK

Funding: Mr A R Weale is supported by the Freemason's Research Fellowship from the Royal College of Surgeons of England.

Conflicts of interest: none declared.

\section{REFERENCES}

1 Fleming CR, Remington M. Intestinal failure. In: Hill GL, ed. Nutrition in the surgical patient. Edinburgh: Churchill Livingstone, 1981:219-35.

2 Bakker $\mathrm{H}$, Bozzetti $F$, Staun $M$, et al. Home parenteral nutrition in adults: a european multicentre survey in 1997. ESPEN-Home Artificial Nutrition Working Group. Clin Nutr 1999; 18:135-40.

3 Richards DM, Irving MH. Assessing the quality of life of patients with intestinal failure on home parenteral nutrition. Gut 1997;40:218-22.

4 Richards DM, Deeks JJ, Sheldon TA, Shaffer JL. Home parenteral nutrition: a systematic review. Health Technol Assess 1997;1:1-59.

5 Buchman AL, Scolapio J, Fryer J. AGA technical review on short bowel syndrome and intestinal transplantation. Gastroenterology 2003;124:1111-34.

6 International Intestinal Transplant Registry 2003. http://www. intestinaltransplantregistry.org

7 Roberts JP, Brown RS Jr, Edwards EB, et al. Liver and intestine transplantation. Am J Transplant 2003;3(suppl 4):78-90.

8 Messing B, Crenn P, Beau P, et al. Long-term survival and parenteral nutrition dependence in adult patients with the short bowel syndrome. Gastroenterology 1999;117:1043-50.

9 Nygaard K. Resection of the small intestine in rats. 3. Morphological changes in the intestinal tract. Acta Chir Scand 1967;133:233-48.

10 Williamson RC. Intestinal adaptation (first of two parts). Structural, functional and cytokinetic changes. N Engl J Med 1978;298:1393-402. 
11 Williamson RC. Intestinal adaptation (second of two parts). Mechanisms of control. N Engl J Med 1978;298:1444-50.

12 Tavakkolizadeh A, Whang EE. Understanding and augmenting human intestinal adaptation: a call for more clinical research. JPEN J Parenter Enteral Nutr 2002;26:251-5.

13 Alpers DH. How adaptable is the intestine in patients with short-bowel syndrome? Am J Clin Nutr 2002;75:787-8

14 Hanson WR, Osborne JW, Sharp JG. Compensation by the residual intestine after intestinal resection in the rat. I. Influence of amount of tissue removed. Gastroenterology 1977;72:692-700.

15 Hines OJ, Bilchik AJ, Zinner MJ, et al. Adaptation of the Na+/glucose cotransporter following intestinal resection. J Surg Res 1994;57:22-7.

16 Ziegler TR, Fernandez-Estivariz C, Gu LH, et al. Distribution of the $\mathrm{H}+$ / peptide transporter PepT1 in human intestine: up-regulated expression in the colonic mucosa of patients with short-bowel syndrome. Am J Clin Nutr 2002;75:922-30.

17 Gouttebel MC, Saint AB, Colette C, et al. Intestinal adaptation in patients with short bowel syndrome. Measurement by calcium absorption. Dig Dis Sci 1989;34:709-15.

18 Nordgaard I, Hansen BS, Mortensen PB. Colon as a digestive organ in patients with short bowel. Lancet 1994;343:373-6.

19 Nightingale JM, Lennard-Jones JE, Gertner DJ, et al. Colonic preservation reduces need for parenteral therapy, increases incidence of renal stones, but does not change high prevalence of gall stones in patients with a short bowel. Gut 1992;33:1493-7.

20 Carbonnel F, Cosnes J, Chevret S, et al. The role of anatomic factors in nutritional autonomy after extensive small bowel resection. JPEN J Parenter Enteral Nutr 1996;20:275-80.

21 Sondheimer JM, Cadnapaphornchai M, Sontag M, et al. Predicting the duration of dependence on parenteral nutrition after neonatal intestinal resection. J Pediatr 1998;132:80-4.

22 Andorsky DJ, Lund DP, Lillehei CW, et al. Nutritional and other postoperative management of neonates with short bowel syndrome correlates with clinical outcomes. J Pediatr 2001;139:27-33.

23 Gruessner RW, Sharp HL. Living-related intestinal transplantation: first report of a standardized surgical technique. Transplantation 1997;64:1605-7.

24 Cicalese L, Baum C, Brown M, et al. Segmental small bowel transplant from adult living-related donors. Transplant Proc 2001;33:1553.

25 Jao W, Sileri P, Holaysan J, et al. Morphologic adaptation following segmental living related intestinal transplantation. Transplant Proc 2002;34:924.

26 Benedetti E, Baum C, Cicalese L, et al. Progressive functional adaptation of segmental bowel graft from living related donor. Transplantation 2001.71:569-71.

27 Bierknes $\mathrm{M}$, Cheng $\mathrm{H}$. Modulation of specific intestinal epithelial progenitors by enteric neurons. Proc Natl Acad Sci USA 2001;98:12497-502.

28 Ponder BA, Schmidt GH, Wilkinson MM, et al. Derivation of mouse intestinal crypts from single progenitor cells. Nature 1985;313:689-91.

29 Cheng $\mathbf{H}$, Leblond $\mathrm{CP}$. Origin, differentiation and renewal of the four main epithelial cell types in the mouse small intestine. V. Unitarian theory of the origin of the four epithelial cell types. Am J Anat 1974;141:537-61.

30 Wong WM, Wright NA. Cell proliferation in gastrointestinal mucosa. J Clin Pathol 1999:52:321-33.

31 Kellett M, Potten CS, Rew DA. A comparison of in vivo cell proliferation measurements in the intestine of mouse and man. Epithelial Cell Biol 1992; 1:147-55

32 Potten CS. The significance of spontaneous and induced apoptosis in the gastrointestinal tract of mice. Cancer Metastasis Rev 1992;11:179-95.

33 Scolapio JS. Tales from the crypt. Gastroenterology 2003;124:561-4.

34 Wu G. Intestinal mucosal amino acid catabolism. J Nutr 1998;128:1249-52.

35 Windmueller HG, Spaeth AE. Identification of ketone bodies and glutamine as the major respiratory fuels in vivo for postabsorptive rat small intestine. J Biol Chem 1978;253:69-76.

36 Welters $\mathrm{CF}$, Dejong $\mathrm{CH}$, Deutz $\mathrm{NE}$, et al. Intestinal function and metabolism in the early adaptive phase after massive small bowel resection in the rat. J Pediatr Surg 2001;36:1746-51.

37 Klimberg VS, Souba WW, Salloum RM, et al. Intestinal glutamine metabolism after massive small bowel resection. Am J Surg 1990; 159:27-32.

38 Deutz NE, Dejong CH, Athanasas G, et al. Partial enterectomy in the rat does not diminish muscle glutamine production. Metabolism 1992;41:1343-50.

39 Alavi K, Kato Y, Yu D, et al. Enteral glutamine does not enhance the effects of hepatocyte growth factor in short bowel syndrome. J Pediatr Surg 1998;33:1666-9.

40 Sukhotnik I, Lerner A, Sabo E, et al. Effects of enteral arginine supplementation on the structural intestinal adaptation in a rat model of short bowel syndrome. Dig Dis Sci 2003:48:1346-51.

41 Michail S, Mohammadpour H, Park JH, et al. Effect of glutaminesupplemented elemental diet on mucosal adaptation following bowe resection in rats. J Pediatr Gastroenterol Nutr 1995;21:394-8.

42 Vanderhoof JA, Blackwood DJ, Mohammadpour $\mathrm{H}$, et al. Effects of oral supplementation of glutamine on small intestinal mucosal mass following resection. J Am Coll Nutr 1992;11:223-7.

43 Wiren ME, Permert J, Skullman SP, et al. No differences in mucosal adaptive growth one week affer intestinal resection in rats given enteral glutamine supplementation or deprived of glutamine. Eur J Surg 1996;162:489-98.

44 Yagi M, Sakamoto K, Inoue T, et al. Effect of a glutamine-enriched elemental diet on regeneration of the small bowel mucosa following isotransplantation of small intestine. Transplant Proc 1994;26:2297-8.
45 Czernichow B, Nsi-Emvo E, Galluser M, et al. Enteral supplementation with ornithine alpha ketoglutarate improves the early adaptive response to resection. Gut 1997;40:67-72.

46 Thiesen AL, Tappenden KA, McBurney MI, et al. Dietary lipids alter the effect of steroids on the transport of glucose after intestinal resection: Part I. Phenotypic changes and expression of transporters. J Pediatr Surg 2003;38:150-60.

47 Koruda MJ, Rolandelli RH, Settle RG, et al. Harry M. Vars award. The effect of a pectin-supplemented elemental diet on intestinal adaptation to massive small bowel resection. JPEN J Parenter Enteral Nutr 1986;10:343-50.

48 Zhang DL, Jiang ZW, Jiang J, et al. D-lactic acidosis secondary to short bowel syndrome. Postgrad Med J 2003;79:110-12.

49 Hairi T, Abumrad NA. Fatty acid transport across membranes: relevance to nutrition and metabolic pathology. Annu Rev Nutr 2002;22:383-415.

50 Hamilton JA. Fatty acid transport: difficult or easy? J Lipid Res 1998;39:467-81.

51 Nordskog BK, Phan CT, Nutting DF, et al. An examination of the factors affecting intestinal lymphatic transport of dietary lipids. Adv Drug Deliv Rev 2001;50:21-44.

52 Sweetser DA, Hauft SM, Hoppe PC, et al. Transgenic mice containing intestinal fatty acid-binding protein-human growth hormone fusion genes exhibit correct regional and cell-specific expression of the reporter gene in their small intestine. Proc Natl Acad Sci USA 1988;85:9611-15.

53 Stahl A. A current review of fatty acid transport proteins (SLC27). Pflugers Arch 2004;447:722-7.

54 Chen $M$, Yang $Y$, Braunstein $E$, et al. Gut expression and regulation of FAT/ CD36: possible role in fatty acid transport in rat enterocytes. Am J Physiol Endocrinol Metab 2001;281:E916-23.

55 Rubin DC, Swietlicki EA, Wang JL, et al. Enterocytic gene expression in intestinal adaptation: evidence for a specific cellular response. Am J Physiol 1996:270:G143-52.

56 Sukhotnik I, Gork AS, Chen M, et al. Effect of low fat diet on lipid absorption and fatty-acid transport following bowel resection. Pediatr Surg Int $2001 ; 17: 259-64$

57 Thiesen A, Wild GE, Tappenden KA, et al. Intestinal resection- and steroidassociated alterations in gene expression were not accompanied by changes in lipid uptake. Digestion 2002;66:112-20.

58 Hart MH, Grandjean CJ, Park JH, et al. Essential fatty acid deficiency and postresection mucosal adaptation in the rat. Gastroenterology 1988:94:682-7.

59 Sukhotnik I, Shiloni E, Krausz MM, et al. Low-fat diet impairs postresection intestinal adaptation in a rat model of short bowel syndrome. J Pediatr Surg 2003;38:1182-7.

60 Kollman-Baverly KA, Thomas DL, Adrian TE, et al. The role of eicosanoids in the process of adaptation following massive bowel resection in the rat. JPEN J Parenter Enteral Nutr 2001;25:275-81.

61 Park JH, Grandjean CJ, Hart MH, et al. Effects of dietary linoleic acid on mucosal adaptation after small bowel resection. Digestion 1989:44:57-65.

62 Vanderhoof JA, Park JH, Herrington MK, et al. Effects of dietary menhaden oil on mucosal adaptation after small bowel resection in rats. Gastroenterology 1994;106:94-9.

63 Vanderhoof JA, Grandjean CJ, Baylor JM, et al. Morphological and functional effects of 16,16-dimethyl-prostaglandin-E2 on mucosal adaptation after massive distal small bowel resection in the rat. Gut 1988;29:802-8

64 Dahly EM, Guo Z, Ney DM. Alterations in enterocyte proliferation and apoptosis accompany TPN-induced mucosal hypoplasia and IGF-I-induced hyperplasia in rats. J Nutr 2002;132:2010-14.

65 Chance WT, Foley-Nelson T, Thomas I, et al. Prevention of parenteral nutrition-induced gut hypoplasia by coinfusion of glucagon-like peptide-2. Am J Physiol 1997:273:G559-63.

66 Gouttebel MC, Astre C, Briand D, et al. Influence of N-acetylglutamine or glutamine infusion on plasma amino acid concentrations during the early phase of small-bowel adaptation in the dog. JPEN J Parenter Enteral Nutr 1992;16:117-21.

$67 \mathrm{Gu}$ Y, Wu ZH, Xie JX, et al. Effects of growth hormone ( $\mathrm{rhGH}$ ) and glutamine supplemented parenteral nutrition on intestinal adaptation in short bowel rats. Clin Nutr 2001;20:159-66.

68 Tamada H, Nezu R, Matsuo Y, et al. Alanyl glutamine-enriched total parenteral nutrition restores intestinal adaptation after either proximal or distal massive resection in rats. JPEN J Parenter Enteral Nutr 1993; 17:236-42.

69 Zhou X, Li YX, Li N, et al. Effect of bowel rehabilitative therapy on structural adaptation of remnant small intestine: animal experiment. World J Gastroenterol 2001;7:66-73.

70 Dahly EM, Gillingham MB, Guo Z, et al. Role of luminal nutrients and endogenous GLP-2 in intestinal adaptation to mid-small bowel resection. Am J Physiol Gastrointest Liver Physiol 2003;284:G670-82.

71 Buchman AL, Moukarzel AA, Ament ME, et al. Effects of total parenteral nutrition on intestinal morphology and function in humans. Transplant Proc 1994;26:1457.

72 van der Hulst RR, van Kreel BK, von Meyenfeldt MF, et al. Glutamine and the preservation of gut integrity. Lancet 1993:341:1363-5.

73 Gorard DA. Enteral nutrition in Crohn's disease: fat in the formula. Eur J Gastroenterol Hepatol 2003;15:115-18.

74 Mclntyre PB, Fitchew M, Lennard-Jones JE. Patients with a high jejunostomy do not need a special diet. Gastroenterology 1986;91:25-33.

75 Cosnes J, Evard D, Beaugerie L, et al. Improvement in protein absorption with a small-peptide-based diet in patients with high jejunostomy. Nutrition 1992;8:406-11. 
76 Nelson LM, Russell RI, Lee FD. Elemental diet composition and the structure and function of rat small intestine: comparison of the effects of two diets on morphology and in vivo absorption of water. JPEN J Parenter Enteral Nutr 1981;5:204-6.

77 Evers BM, Izukura M, Townsend CM Jr, et al. Neurotensin prevents intestinal mucosal hypoplasia in rats fed an elemental diet. Dig Dis Sci 1992;37:426-31.

78 Shulman DI, Hu CS, Duckett G, et al. Effects of short-term growth hormone therapy in rats undergoing $75 \%$ small intestinal resection. J Pediatr Gastroenterol Nutr 1992;14:3-11.

79 Benhamou PH, Canarelli JP, Leroy C, et al. Stimulation by recombinant human growth hormone of growth and development of remaining bowel after subtotal ileojejunectomy in rats. J Pediatr Gastroenterol Nutr 1994; 18:446-52.

80 Wheeler EE, Challacombe DN. The trophic action of growth hormone insulin-like growth factor-l, and insulin on human duodenal mucosa cultured in vitro. Gut 1997;40:57-60.

81 Lund PK. Molecular basis of intestinal adaptation: the role of the insulin-like growth factor system. Ann N Y Acad Sci 1998:859:18-36.

82 Ryan J, Costigan DC. Determination of the histological distribution of insulin like growth factor 1 receptors in the rat gut. Gut 1993;34:1693-7.

83 Furstenberger G, Senn HJ. Insulin-like growth factors and cancer. Lancet Oncol 2002;3:298-302.

84 Peterson CA, Carey HV, Hinton PL, et al. GH elevates serum IGF-I levels but does not alter mucosal atrophy in parenterally fed rats. Am J Physiol 1997;272:G1100-8

85 Ziegler TR, Mantell MP, Chow JC, et al. Gut adaptation and the insulin-like growth factor system: regulation by glutamine and IGF-I administration. Am J Physiol 1996;271:G866-75.

86 Peterson CA, Gillingham MB, Mohapatra NK, et al. Enterotrophic effect of insulin-like growth factor-l but not growth hormone and localized expression of insulin-like growth factor-I, insulin-like growth factor binding protein-3 and -5 mRNAs in jejunum of parenterally fed rats. JPEN J Parenter Enteral Nutr 2000;24:288-95.

87 Kuemmerle JF, Zhou H. Insulin-like growth factor-binding protein-5 (IGFBP-5) stimulates growth and IGF-I secretion in human intestinal smooth muscle by Ras-dependent activation of p38 MAP kinase and Erk1/2 pathways. J Biol Chem 2002;277:20563-71

88 Hankinson SE, Willett WC, Colditz GA, et al. Circulating concentrations of insulin-like growth factor-I and risk of breast cancer. Lancet 1998;351:1393-6.

89 Chan JM, Stampfer MJ, Giovannucci E, et al. Plasma insulin-like growth factor-I and prostate cancer risk: a prospective study. Science 1998;279:563-6

$90 \mathrm{Ma} \mathrm{J}$, Pollak MN, Giovannucci E, et al. Prospective study of colorectal cance risk in men and plasma levels of insulin-like growth factor (IGF)-I and IGFbinding protein-3. J Natl Cancer Inst 1999;91:620-5.

91 Lukanova A, Toniolo P, Akhmedkhanov A, et al. A prospective study of insulin-like growth factor-I, IGF-binding proteins-1, -2 and -3 and lung cancer risk in women. Int J Cancer 2001;92:888-92.

92 Drucker DJ, DeForest L, Brubaker PL. Intestinal response to growth factors administered alone or in combination with human [Gly2] glucagon-like peptide 2. Am J Physiol 1997;273:G1252-62.

93 Iwamoto R, Mekada E. Heparin-binding EGF-like growth factor: a juxtacrine growth factor. Cytokine Growth Factor Rev 2000;11:335-44.

94 Howarth GS, Shoubridge CA. Enhancement of intestinal growth and repair by growth factors. Curr Opin Pharmacol 2001;1:568-74.

95 Welters $\mathrm{CF}$, Dejong $\mathrm{CH}$, Deutz NE, Heineman E. Intestinal adaptation in short bowel syndrome. Aust N Z J Surg 2002;72:229-36.

96 Shin CE, Helmrath MA, Falcone RA Jr, et al. Epidermal growth factor augments adaptation following small bowel resection: optimal dosage, route, and timing of administration. J Surg Res 1998;77:11-16.

97 Erwin CR, Helmrath MA, Shin CE, et al. Intestinal overexpression of EGF in transgenic mice enhances adaptation after small bowel resection. Am J Physiol 1999;277:G533-40

98 Helmrath MA, Shin CE, Fox JW, et al. Adaptation after small bowel resection is attenuated by sialoadenectomy: the role for endogenous epidermal growth factor. Surgery 1998;124:848-54

99 O'Brien DP, Nelson LA, Williams JL, et al. Selective inhibition of the epidermal growth factor receptor impairs intestinal adaptation after small bowel resection. J Surg Res 2002;105:25-30.

100 Murphy MS. Growth factors and the gastrointestinal tract. Nutrition 1998; 14:771-4

101 Malden LT, Novak U, Burgess AW. Expression of transforming growth factor alpha messenger RNA in the normal and neoplastic gastro-intestinal tract. Int J Cancer 1989:43:380-4.

102 Sukhotnik I, Yakirevich E, Coran AG, et al. Effect of transforming growth factor-alpha on intestinal adaptation in a rat model of short bowel syndrome. J Surg Res 2002;108:235-42.

103 Higashiyama S, Abraham JA, Miller J, et al. A heparin-binding growth factor secreted by macrophage-like cells that is related to EGF. Science $1991 ; 251: 936-9$.

104 Xia G, Martin AE, Michalsky MP, et al. Heparin-binding EGF-like growth factor preserves crypt cell proliferation and decreases bacterial translocation after intestinal ischemia/reperfusion injury. J Pediatr Surg 2002;37:1081-7.

105 Ellis PD, Hadfield KM, Pascall JC, et al. Heparin-binding epidermal-growthfactor-like growth factor gene expression is induced by scrape-wounding epithelial cell monolayers: involvement of mitogen-activated protein kinase cascades. Biochem J 2001;354:99-106.
106 Mulligan C, Rochford J, Denyer G, et al. Microarray analysis of insulin and insulin-like growth factor-1 (IGF-1) receptor signaling reveals the selective up-regulation of the mitogen heparin-binding EGF-like growth factor by IGF-1. J Biol Chem 2002;277:42480-7.

107 Holst JJ. Enteroglucagon. Annu Rev Physiol 1997:59:257-71.

108 Drucker DJ, Erlich P, Asa SL, et al. Induction of intestinal epithelial proliferation by glucagon-like peptide 2. Proc Natl Acad Sci USA 1996;93:7911-16.

109 Jasleen J, Ashley SW, Shimoda N, et al. Glucagon-like peptide 2 stimulates intestinal epithelial proliferation in vitro. Dig Dis Sci 2002:47:1135-40.

110 Scott RB, Kirk D, MacNaughton WK, et al. GLP-2 augments the adaptive response to massive intestinal resection in rat. Am J Physiol 1998;275:G911-21

111 Yusta B, Huang L, Munroe D, et al. Enteroendocrine localization of GLP-2 receptor expression in humans and rodents. Gastroenterology 2000;1 19:744-55.

112 Jeppesen PB, Hartmann B, Hansen BS, et al. Impaired meal stimulated glucagon-like peptide 2 response in ileal resected short bowel patients with intestinal failure. Gut 1999:45:559-63.

113 Kato Y, Yu D, Schwartz MZ. Enhancement of intestinal adaptation by hepatocyte growth factor. J Pediatr Surg 1998;33:235-9.

114 Kato Y, Yu D, Schwartz MZ. Hepatocyte growth factor up-regulates SGLT and GLUT5 gene expression after massive small bowel resection. J Pediatr Surg 1998;33:13-15.

115 Wildhaber BE, Yang H, Teitelbaum DH. Total parenteral nutrition-induced apoptosis in mouse intestinal epithelium: modulation by keratinocyte growth factor. J Surg Res 2003;112:144-51.

116 Yang H, Antony PA, Wildhaber BE, et al. Intestinal intraepithelial lymphocyte gammadelta-T cell-derived keratinocyte growth factor modulates epithelial growth in the mouse. J Immunol 2004;172:4151-8.

117 Johnson WF, DiPalma CR, Ziegler TR, et al. Keratinocyte growth factor enhances early gut adaptation in a rat model of short bowel syndrome. Vet Surg 2000;29:17-27.

118 Yang H, Wildhaber BE, Teitelbaum DH. 2003 Harry M. Vars Research Award. Keratinocyte growth factor improves epithelial function after massive small bowel resection. JPEN J Parenter Enteral Nutr 2003;27:198-206.

119 Izukura M, Evers BM, Parekh D, et al. Neurotensin augments intestinal regeneration after small bowel resection in rats. Ann Surg 1992;215:520-6.

120 De Miguel E, Gomez dS I, Bonet H, et al. Trophic effects of neurotensin in massive bowel resection in the rat. Dig Dis Sci 1994;39:59-64.

121 Pearson PY, O'Connor DM, Schwartz MZ. Novel effect of leptin on small intestine adaptation. J Surg Res 2001;97:192-5.

122 Lostao MP, Urdaneta E, Martinez-Anso E, et al. Presence of leptin receptors in rat small intestine and leptin effect on sugar absorption. FEBS Lett 1998;423:302-6

123 Alavi K, Schwartz MZ, Prasad R, et al. Leptin: a new growth factor for the small intestine. J Pediatr Surg 2002;37:327-30.

124 Du X, Williams DA. Interleukin-11: review of molecular, cell biology, and clinical use. Blood 1997;89:3897-908.

125 Orazi A, Du X, Yang Z, et al. Interleukin-11 prevents apoptosis and accelerates recovery of small intestinal mucosa in mice treated with combined chemotherapy and radiation. Lab Invest 1996;75:33-42.

126 Gibson RJ, Keefe DM, Thompson FM, et al. Effect of interleukin-11 on ameliorating intestinal damage after methotrexate treatment of breast cancer in rats. Dig Dis Sci 2002;47:2751-7.

127 Fiore NF, Ledniczky G, Liu Q, et al. Comparison of interleukin-11 and epidermal growth factor on residual small intestine after massive small bowel resection. J Pediatr Surg 1998;33:24-9.

128 Alavi K, Prasad R, Lundgren K, et al. Interleukin- 11 enhances small intestine absorptive function and mucosal mass after intestinal adaptation. J Pediatr Surg 2000;35:371-4.

129 Byrne TA, Persinger RL, Young LS, et al. A new treatment for patients with short-bowel syndrome. Growth hormone, glutamine, and a modified diet. Ann Surg 1995;222:243-54.

130 Byrne TA, Morrissey TB, Nattakom TV, et al. Growth hormone, glutamine, and a modified diet enhance nutrient absorption in patients with severe short bowel syndrome. JPEN J Parenter Enteral Nutr 1995;19:296-302.

131 Byrne TA, Cox S, Karimbakas M, et al. Bowel rehabilitation: an alternative to long-term parenteral nutrition and intestinal transplantation for some patients with short bowel syndrome. Transplant Proc 2002;34:887-90.

132 Scolapio JS, Camilleri M, Fleming CR, et al. Effect of growth hormone, glutamine, and diet on adaptation in short-bowel syndrome: a randomized, controlled study. Gastroenterology 1997;113:1074-81.

133 Scolapio JS. Effect of growth hormone, glutamine, and diet on body composition in short bowel syndrome: a randomized, controlled study. JPEN J Parenter Enteral Nutr 1999:23:309-12.

134 Szkudlarek J, Jeppesen PB, Mortensen PB. Effect of high dose growth hormone with glutamine and no change in diet on intestinal absorption in short bowel patients: a randomised, double blind, crossover, placebo controlled study. Gut 2000:47:199-205.

135 Seguy D, Vahedi K, Kapel N, et al. Low-dose growth hormone in adult home parenteral nutrition-dependent short bowel syndrome patients: a positive study. Gastroenterology 2003;124:293-302

136 Jeppesen PB, Hartmann B, Thulesen J, et al. Elevated plasma glucagon-like peptide 1 and 2 concentrations in ileum resected short bowel patients with a preserved colon. Gut 2000;47:370-6.

137 Jeppesen PB, Hartmann B, Thulesen J, et al. Glucagon-like peptide 2 improves nutrient absorption and nutritional status in short-bowel patients with no colon. Gastroenterology 2001;120:806-15. 